Jurnal Keperawatan Silampari

Volume 3, Nomor 1, Desember 2019

e-ISSN: 2581-1975

p-ISSN: 2597-7482

DOI: https://doi.org/10.31539/jks.v3i1.512

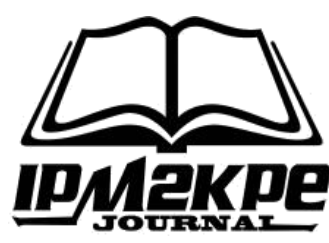

\title{
GAMBARAN NYERI PUNGGUNG BAWAH PADA IBU HAMIL TRIMESTER III
}

\author{
Kurniati Devi Purnamasari ${ }^{1}$, Melyana Nurul Widyawati ${ }^{2}$ \\ Program Kebidanan Sains Terapan Pascasarjana, Poltekkes Kemenkes Semarang ${ }^{1,2}$ \\ kurniatidevip@gmail.com ${ }^{1}$
}

\begin{abstract}
ABSTRAK
Tujuan Penelitian ini dilakukan untuk menggambarkan nyeri punggung bawah pada ibu hamil trimester III. Metode yang digunakan adalah desain studi deskriptif potong lintang. Hasil penelitian, responden yang mengalami nyeri ringan sebanyak 20\%, 50\% mengalami nyeri sedang dan sebanyak $30 \%$ mengalami nyeri berat disertai dengan gejala penyerta. Meski merupakan suatu masalah, $82 \%$ remaja hanya membiarkan saja saat nyeri timbul atau hanya minum air hangat dan menekan bagian yang sakit (18\%). Para ibu hamil trimester III mencari pertolongan kepada suami dan keluarga $(87,2 \%)$ mengenai masalah yang timbul dan hanya, $12,8 \%$ dari ibu hamil trimester III yang mencari pertolongan ke tenaga kesehatan/ bidan. Simpulan, sebagian besar responden pernah mengalami nyeri otot punggung bawah. Umumnya informasi tentang punggung bawah paling banyak didapatkan dari wanita hamil lainnya dan orangtua. Saat mengalami punggung bawah sebagian besar ibu hamil meminta pertolongan kepada suami dan keluarga.
\end{abstract}

Kata Kunci: Ibu Hamil Trimester III, Nyeri Punggung Bawah

\section{ABSTRACT}

The purpose of this study was to describe low back pain in third trimester pregnant women. The method used is a cross sectional descriptive study design. The results of the study, respondents who experienced mild pain as much as 20\%, 50\% experienced moderate pain and as many as $30 \%$ experienced severe pain accompanied by accompanying symptoms. Although it is a problem, $82 \%$ of adolescents only let go when pain arises or only drink warm water and press on the affected part (18\%). Third trimester pregnant women seek help from their husbands and families (87.2\%) regarding problems that arise and only, $12.8 \%$ of third trimester pregnant women seek help from health workers / midwives. In conclusion, most respondents have experienced low back muscle pain. Generally, information about the lower back is mostly obtained from other pregnant women and parents. When experiencing low back most pregnant women ask for help from their husbands and families.

Keywords: Trimester III Pregnant Women, Lower Back Pain 


\section{PENDAHULUAN}

Kehamilan merupakan suatu proses yang alami dan normal. Selama hamil seorang ibu mengalami perubahan-perubahan yang terjadi baik fisik maupun psikologis. Perubahanperubahan tersebut menyebabkan ibu hamil mengalami ketidaknyamanan (Manuaba, 2010). Kehamilan adalah periode unik dalam kehidupan yang terkait dengan perubahan hormonal dan fisiologis lainnya pada seorang wanita hamil, yang dapat memicu atau mengubah jalannya gangguan neurologis dan kejiwaan. Selain itu, banyak prosedur diagnostik yang dapat dilakukan pada wanita normal tidak hamil yang dilarang selama kehamilan untuk alasan kesehatan ibu hamil. Keputusan terapeutik dan manajemen pasien hamil dengan keluhan nyeri sangat tergantung pada masalah keseimbangan yang wajar terjadi selama kehamilan, yang dikaitkan antara risiko yang terjadi tanpa adanya pengobatan versus pengobatan aktif untuk ibu dan janinnya (Elsevier 2011).

Berbagai masalah yang timbul pada kehamilan trimester III merupakan masalah psikologis yang sering dikeluhkan pada ibu hamil, seperti kecemasan dan nyeri (Hartvigsen et al, 2018), Di antara keluhan tersebut, nyeri punggung bawah yang paling umum dilaporkan, terjadi pada 60\%-90\% ibu hamil, dan merupakan salah satu penyebab angka kejadian persalinan sesar.

Rasa tidak nyaman yang dirasakan oleh ibu hamil biasanya berbeda-beda pada setiap trimester kehamilan. Perubahan yang terjadi selama kehamilan sering kali menjadi keluhan bagi ibu hamil diantaranya adalah mual muntah pada awal kehamilan, konstipasi, varises vena (pembuluh balik), gangguan berkemih, hemoroid, dan pembengkakan pada tungkai dan kaki serta nyeri punggung (Bobak, 2010).

Wanita hamil yang mengalami nyeri punggung sekitar $88,2 \%$. Wanita hamil usia kehamilan 14-22 minggu mengalami kejadian nyeri punggung bawah sekitar $62 \%$. Nyeri pada punggung selama kehamilan bervariasi antara 35-60\%. Hasil penelitian Ariyanti (2012) didapatkan bahwa 68\% ibu hamil mengalami nyeri punggung dengan intensitas sedang, dan $32 \%$ ibu hamil mengalami nyeri punggung dengan intensitas ringan. Diantara semua wanita ini, 47-60\% melaporkan bahwa nyeri punggung terjadi pada kehamilan 5-7 bulan (Renata, 2009).

Perubahan ini disebabkan oleh berat uterus yang membesar, membungkuk yang berlebihan, berjalan tanpa istirahat, dan angkat beban. Gejala nyeri punggung ini juga disebabkan oleh hormon estrogen dan progesteron yang mengendurkan sendi, ikatan tulang dan otot dipinggul (Tiran, 2008).

Nyeri merupakan masalah yang sangat sering terjadi pada kehamilan khususnya pada trimester III kehamilan. Fenomena nyeri saat ini telah menjadi masalah kompleks yang didefinisikan oleh international society for the study of pain sebagai "pengalaman sensorik dan emosi yang tidak menyenangkan akibat kerusakan jaringan, baik aktual maupun potensial". Nyeri menyebabkan ketakutan dan kecemasan sehingga dapat meningkatkan stres dan perubahan fisiologis yang dratis selama kehamilan. Nyeri dan kecemasan bekerja secara sinergis, yang saling memperburuk satu sama lain (Carvalho et al. 2017a; Durand, Plata 2017; Burns et al, 2018). Fenomena nyeri pada bagian punggung ibu hamil adalah salah satu keluhan yang paling sering dilaporkan di kalangan ibu hamil, bervariasi dari 50\% sampai 70\%, berdasarkan pada penelitian di berbagai negara sebelumnya (Yan et al, 2014), bahkan 8\% diantaranya mengakibatkan kecacatan berat (Lee, 2016). Namun, hanya ada sedikit bukti empiris yang menunjukkan bahwa hal ini telah berdampak di bidang perawatan individu yang menderita nyeri, nyeri akut yang ditangani dengan buruk meningkatkan risiko rasa sakit terus-menerus, mengurangi kualitas hidup dan meningkatkan penggunaan layanan kesehatan yang bersifat kuratif (Nickel et al, 2018). Meskipun angka kejadiannya cukup tinggi, masih 
sedikit para ibu hamil yang mencari informasi mengenai masalah yang timbul pada nyeri punggung bawah selama kehamilan dan dampaknya. Tersedianya informasi mengenai nyeri selama kehamilan dan permasalahannya, khususnya nyeri punggung bawah pada trimester III merupakan hal yang penting untuk perkembangan pelayanan kesehatan bagi ibu hamil. Tujuan penelitian untuk mengetahui gambaran nyeri punggung bawah pada ibu hamil trimester III.

\section{METODE PENELITIAN}

Penelitian dilakukan di Puskesmas Ngesrep menggunakan desain studi deskriptif dengan metode potong lintang, pada bulan Mei 2018. Subjek penelitian adalah Ibu hamil trimester III yang melakukan kunjungan Antenatal Care (ANC) di Puskesmas Ngesrep. Teknik sampling dalam penelitian ini adalah non probability sampling jenis consecutive sampling, yaitu semua subjek yang datang ke Puskesmas Ngesrep secara berurutan dan memenuhi kriteria dimasukkan dalam penelitian sampai jumlah subjek yang diperlukan terpenuhi. Kuesioner penelitian menggunakan kuisioner Visual Analog Scale (VAS) dan kuesioner yang terdiri dari 3 pertanyaan yang antara lain mengenai derajat nyeri yang dialami oleh ibu, lama nyeri, ke mana para remaja mencari pertolongan bila mengalami nyeri punggung bawah, dan apa yang dilakukan untuk mengurangi nyeri punggung yang timbul. Berdasarkan berat ringannya gejala nyeri, nyeri punggung bawah dikelompokkan menjadi derajat ringan bila nyeri ringan yang tidak mengganggu aktivitas sehari-hari ibu (skala 1-3), derajat sedang bila nyeri sedang yang bisa mengganggu aktivitas sehari-hari tetapi masih bisa beraktivitas normal (skala 4-7), sedangkan derajat berat bila nyeri hebat dan ibu tidak dapat melakukan kegiatannya dan hanya bisa tirah baring (skala 8-10).

Skala Visual Analog Scale (VAS) yang digunakan dalam penelitian ini ditunjukkan oleh gambar 1 .

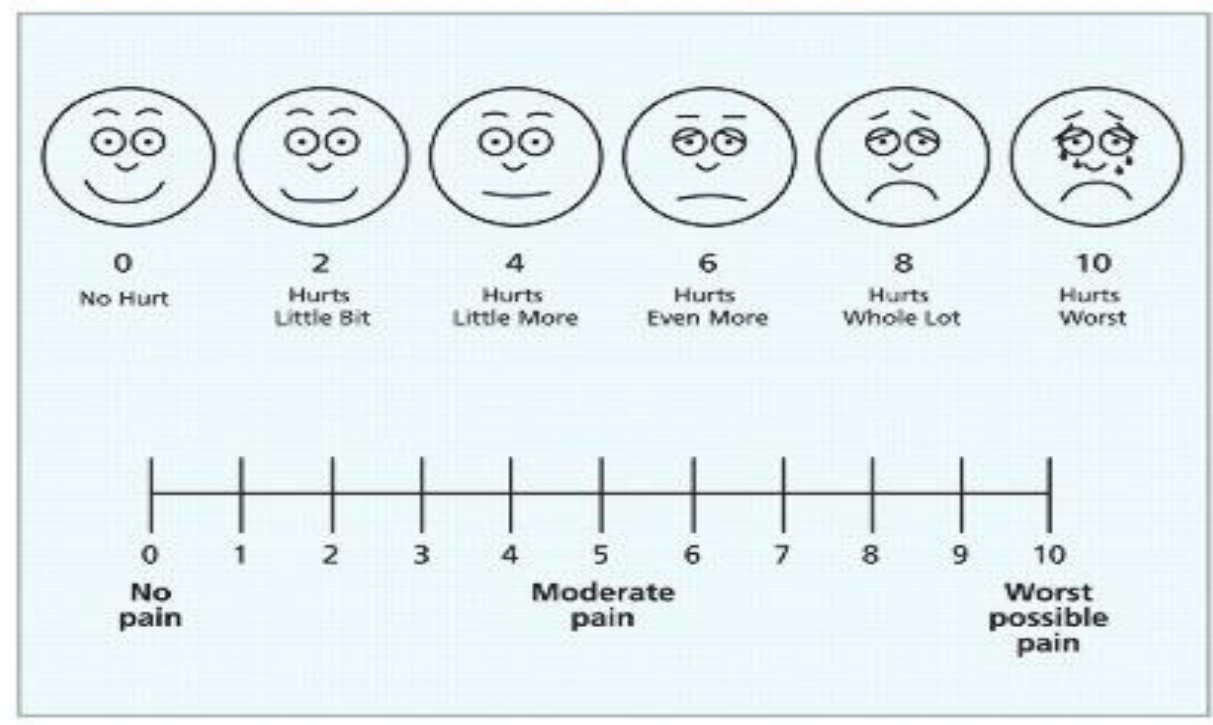

Gambar. 1

Visual Analog Scale (VAS)

Sumber : Carvalho (2015) 
Sebelum pengisian kuesioner, responden diberikan penjelasan dan dimintakan persetujuan responden untuk mengikuti penelitian. Data dianalisis dengan program komputerisasi. Definisi nyeri punggung bawah adalah keluhan nyeri dan rasa tegang atau kaku pada otot, yang terlokalisasi di area costae dan di atas lipatan gluteus inferior dengan atau tanpa nyeri menjalar ke tungkai.

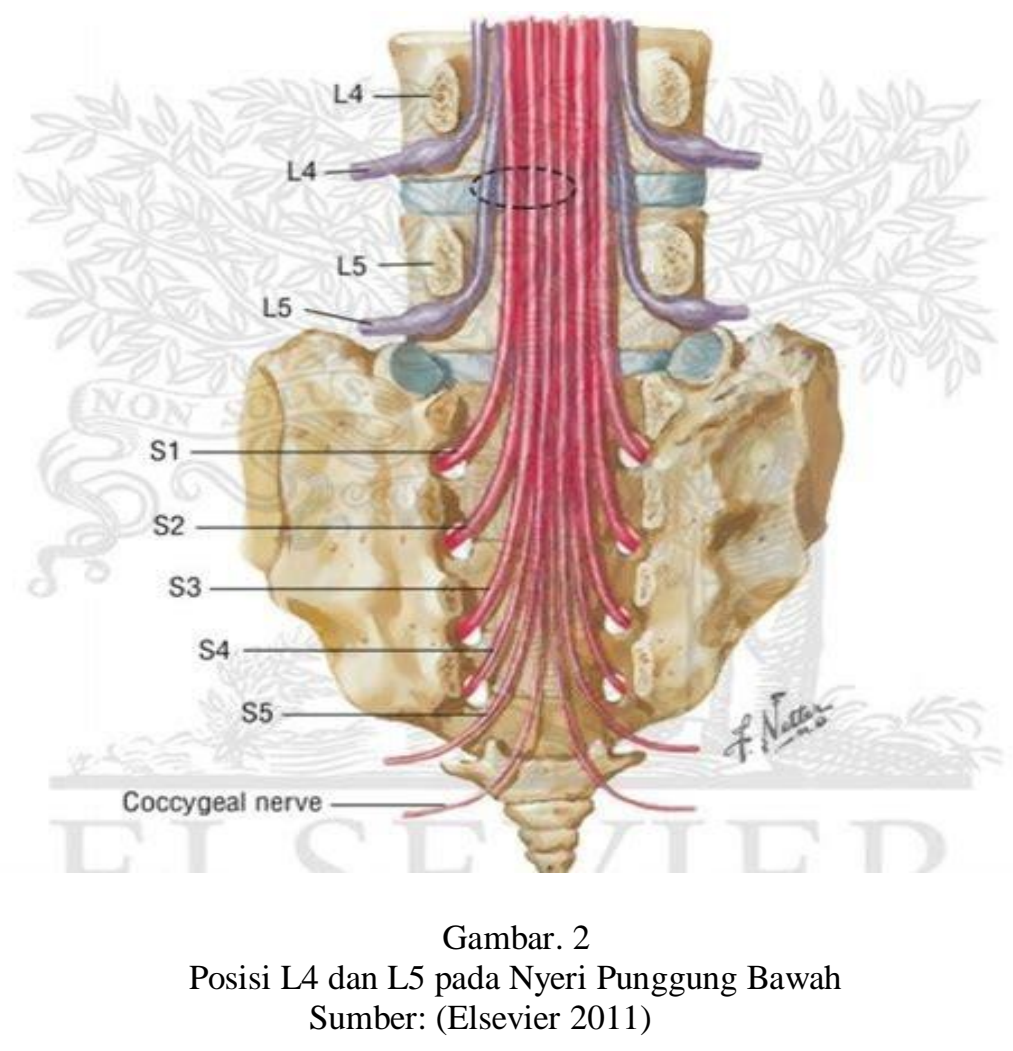

\section{HASIL PENELITIAN}

Karakteristik dalam penelitian ini terdiri dari usia ibu, paritas, umur kehamilan, Tinggi Fundus Uteri (TFU), Tinggi Badan (TB), Berat Badan (BB), Skala Visual Analog Scale (VAS) nyeri punggung bawah.

Tabel. 1

Karakteristik Responden

\begin{tabular}{lccc}
\hline \multicolumn{1}{c}{ Karakteristik } & Min & Max & Mean \pm SD \\
\hline Umur Ibu (tahun) & 21 & 30 & $24,73 \pm 2,71$ \\
Hamil ke- & 1 & 2 & $1,53 \pm 0,52$ \\
Umur Kehamilan (minggu) & 28 & 38 & $27,26 \pm 7,40$ \\
TFU $(\mathrm{cm})$ & 12 & 30 & $23,93 \pm 7,03$ \\
TB $(\mathrm{cm})$ & 152 & 167 & $156,46 \pm 4,25$ \\
BB $(\mathrm{kg})$ & 40 & 80 & $62,36 \pm 14,69$ \\
Skala VAS & 5 & 10 & $6,33 \pm 1,63$ \\
\hline
\end{tabular}

Berdasarkan tabel 1 dapat dilihat dari sebanyak 30 orang subjek yang diteliti bahwa karakteristik umur ibu nilai rata-ratanya adalah $(24,73 \pm 2,71)$ tahun dengan rentang umur responden adalah 21- 30 tahun. Paritas rata-rata responden adalah $(1,53 \pm$ $0,52)$ dengan rentang kehamilan 1-2. Rata-rata umur kehamilan responden adalah 
$(27,26 \pm 7,40)$ minggu dengan rentang umur kehamilan $28-38$ minggu. Rata-rata TFU responden adalah $(23,93 \pm 7,03) \mathrm{cm}$ dengan rentang $12-30 \mathrm{~cm}$. Rata-rata tinggi badan responden adalah $(156,46 \pm 4,25) \mathrm{cm}$ dengan rentang $152-167 \mathrm{~cm}$. Rata -rata berat badan responden adalah $(62,36 \pm 14,69) \mathrm{kg}$ dengan rentang berat badan $40-80 \mathrm{~kg}$. Ratarata Indeks Massa Tubuh (IMT) responden adalah $(25,45 \pm 5,72)$ dengan rentang Indek Massa Tubuh (IMT). Rata-rata skala nyeri Visual Analog Scale (VAS) responden adalah $(6,33 \pm 1,63)$ dengan rentang skala nyeri 5-10.

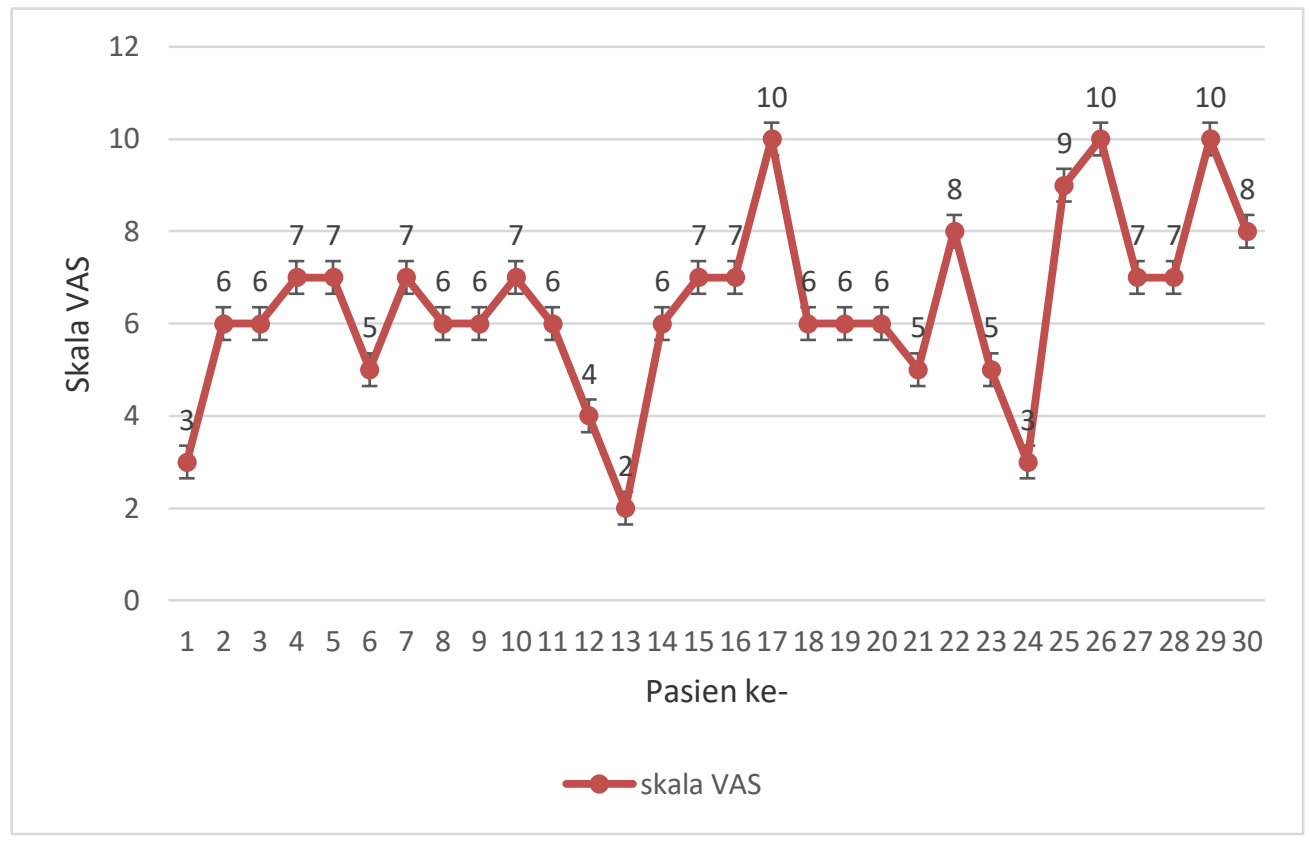

Gambar. 3

Tren Skala Nyeri Otot Punggung Bawah dengan Menggunakan Visual Analogue Scale (VAS)

Gambaran pengukuran nyeri punggung bawah menggunakan Visual Analog Scale (VAS) ini ditunjukkan dengan tabel Gambar 3. Berdasarkan Gambar 3 menunjukkan bahwa nyeri punggung bawah yang dialami oleh responden ibu hamil trimester III sebanyak $3(10 \%)$ orang dengan skala nyeri VAS ringan, sebanyak 22 orang $(73,33 \%)$ dengan skala nyeri VAS sedang dan skala nyeri VAS berat sebanyak 5 orang $(16,67 \%)$.

Sebanyak 30 kuesioner diberikan kepada responden dan responden bersedia mengisi kuesioner. Didapatkan $30(100 \%)$ responden pernah mengalami nyeri punggung bawah selama kehamilan.

Tabel. 2

Distribusi Responden Nyeri Punggung Bawah Berdasarkan Derajat Nyeri, Lama Nyeri, Gejala Penyerta, dan Tempat Mencari Pertolongan

\begin{tabular}{|c|c|c|c|c|c|}
\hline \multirow[t]{2}{*}{ Variabel } & \multirow[t]{2}{*}{$(n=30)$} & \multicolumn{4}{|c|}{ Tempat mencari pertolongan } \\
\hline & & Suami & keluarga & bidan & Lain-lain \\
\hline \multicolumn{6}{|l|}{ Derajat nyeri } \\
\hline Ringan & $3(10 \%)$ & $1(33,33 \%)$ & $2(66,67 \%)$ & 0 & 0 \\
\hline Sedang & $22(73,33 \%)$ & $20(90,90 \%)$ & $2(9,10 \%)$ & 0 & 0 \\
\hline Berat & $5(16,67 \%)$ & $2(40 \%)$ & $1(20 \%)$ & $2(20 \%)$ & \\
\hline
\end{tabular}




\begin{tabular}{lccccc}
\hline Lama nyeri & & & & & \\
$<24$ jam & $26(86,66 \%)$ & $21(80,76 \%)$ & $4(15,38 \%)$ & $1(3,86 \%)$ & 0 \\
1 hari & $2(6,67 \%)$ & $2(100 \%)$ & 0 & 0 & 0 \\
$\begin{array}{l}\text { Beberapa hari } \\
\text { Gejala penyerta }\end{array}$ & $2(6,67 \%)$ & 0 & 0 & $2(100 \%)$ & 0 \\
$\begin{array}{l}\text { Tanpa gejala } \\
\text { Ada gejala }\end{array}$ & $28(93,33 \%)$ & $20(71,42 \%)$ & $7(28,58 \%)$ & 0() & 0 \\
\hline
\end{tabular}

Berdasarkan tabel 2 di atas dapat dilihat bahwa pada ibu hamil yang mengalami nyeri punggung bawah, sebagian besar $(73,33 \%)$ mengalami nyeri sedang, sedangkan yang mengalami nyeri ringan dan berat $10 \%$ dan 16,67\%. Dijumpai 26 orang $(86,66 \%)$ responden mengalami nyeri punggung bawah kurang dari 24 jam, 6,67\% mengalami nyeri berlangsung selama satu hari, dan $6,67 \%$ sampai beberapa hari. Sebagian besar $(93,33 \%)$ responden mengalami dismenorea tidak disertai gejala penyerta dan $6,67 \%$ disertai gejala penyerta. Gejala penyerta yang dilaporkan yaitu mual muntah (50\%) dan kecenderungan mudah marah atau gangguan emosi (50\%). Pada Tabel 2 tertera bahwa pada nyeri sedang paling banyak meminta pertolongan pada suami $(90,90 \%)$. responden yang mengalami nyeri punggung bawah dengan nyeri berat paling banyak meminta pertolongan kepada teman suami (40\%) bukan kepada bidan.

Tabel. 3

Distribusi Responden Berdasarkan Cara Mengurangi Rasa Nyeri saat Mengalami Nyeri Punggung Bawah

\begin{tabular}{lcc}
\hline \multicolumn{1}{c}{ Variabel } & Jumlah $(\mathrm{n}=30)$ & Persentase \\
\hline Analgetik & 2 & 6,67 \\
Minum air hangat/dipijat & 21 & 70 \\
Periksa ke bidan & 2 & 6,67 \\
Dibiarkan saja & 5 & 16,66 \\
\hline
\end{tabular}

Meskipun nyeri punggung bawah pada ibu hamil trimester III merupakan suatu masalah yang dapat menimbulkan nyeri dari ringan sampai berat, namun seperti yang tampak pada Tabel 3 para responden lebih memilih minum air hangat/ memijat area punggung bawah saat terjadi nyeri (70\%), atau dibiarkan saja karena nyeri akan hilang dengan sendirinya (16,66\%). Responden yang lain $(6,67 \%)$ memilih menggunakan analgetik, seperti parasetamol atau obat-obatan yang dapat menghilangkan rasa nyeri haid, dan $(6,67 \%)$ lainnya yang melakukan pemeriksaan ke bidan.

Tabel. 4

Distribusi Responden Berdasarkan Sumber Informasi

\begin{tabular}{lcc}
\hline \multicolumn{1}{c}{ Variabel } & Jumlah $(\mathrm{n}=30)$ & Persentase \\
\hline Suami & 2 & 6,67 \\
Keluarga & 21 & 70 \\
Bidan & 6 & 20 \\
Lain-lain & 1 & 3,33 \\
\hline
\end{tabular}

Sebagian besar ibu hamil lebih menyukai mencari informasi tentang nyeri punggung bawah pada keluarga $(70 \%)$ dan bidan $(23,33 \%)$ dibandingkan dengan informasi dari suami $(6,67 \%)$. Mereka juga mencari informasi dari sumber-sumber lain seperti majalah, koran, ataupun internet $(3,33 \%)$. 


\section{PEMBAHASAN}

Berdasarkan penelitian yang kami lakukan didapatkan bahwa dari sejumlah 30 orang responden sebagian besar $(73,33 \%)$ mengalami nyeri sedang, sedangkan yang mengalami nyeri ringan dan berat $10 \%$ dan $16,67 \%$. Nyeri punggung bawah adalah penyebab paling sering kecacatan jangka panjang di seluruh dunia (Lima et al, 2018) dengan prevalensi sebanyak 6 dari 10 orang ibu hamil di dunia mengalami nyeri punggung bawah selama kehamilannya (Golob, Wipf 2014). Selama kehamilan, relaksasi sendi di bagian sekitar panggul dan punggung bawah ibu hamil kemungkinan terjadi akibat perubahan hormonal. Sejalan dengan bertambahnya berat badan secara bertahap selama kehamilan dan redistribusi pemusatan terdapat pengaruh hormonal pada struktur otot yang terjadi selama kehamilan. Kedua faktor ini mengakibatkan adanya perubahan postur tubuh pada ibu hamil. Perubahan sistem muskuloskeletal terjadi pada saat umur kehamilan semakin bertambahnya kehamilan (Darwich, Diwan 2009). Adaptasi muskuloskelatal ini mencakup: peningkatan berat badan, bergesernya pusat berat tubuh akibat pembesaran rahim, relaksasi dan mobilitas. Semakin besar kemungkinan instabilitas sendi sakroiliaka dan peningkatan lordosis lumbal, yang menyebabkan rasa sakit (Carvalho et al, 2017b).

Adanya nyeri hebat menyebabkan reaksi reflekstorik pada otot-otot lumbo dorsal terutama otot erector spine pada L4 dan L5 sehingga terjadi peningkatan tonus yang terlokalisir (spasme) sebagai "guarding" (penjagaan) terhadap adanya gerakan. Jika spasme otot berlangsung lama maka otot akan cenderung menjadi tightness. Keadaan tightness pada otot-otot erector spine akan memperberat nyeri karena terjadi ischemic dan menyebabkan alignment spine menjadi abnormal sehingga menimbulkan beban stres/kompresi yang besar pada diskus intervertebralis yang cedera (Golob, Wipf, 2014).

Adanya kerusakan menyebabkan terlepasnya zat-zat iritan seperti prostaglandin, bradykinin, dan histamin sehingga merangsang serabut saraf $\mathrm{A} \delta$ dan tipe $\mathrm{C}$ (bermylein tipis). Impuls tersebut dibawa ke ganglion dorsalis danmasuk kedalam medulla spinalis melalui cornu dorsalis, yang kemudian dibawa ke level sistem saraf pusat yang lebih tinggi melalui traktus spinothalamicus dan spinoreticularis. Adanya rangsangan pada ganglion dorsalis akan memicu produksi "P" substance. Produksi "P"substance akan merangsang terjadinya reaksi inflamasi.

Hal ini mengindikasikan adanya kecenderungan bagi otot untuk memendek jika otot abdomen meregang sehingga dapat menyebabkan ketidakseimbangan otot disekitar panggul dan punggung bawah, dan tegangan tambahan dapat dirasakan diatas ligamen tersebut. Akibatnya nyeri punggung yang biasanya berasal dari sakroiliaka atau lumbar, dan dapat menjadi gangguan punggung jangka panjang jika keseimbangan otot dan stabilitas pelvis tidak dipulihkan setelah melahirkan dan postpartum. Diperkirakan bahwa sekitar 50\% wanita hamil mengeluhkan beberapa jenis nyeri punggung di beberapa titik kehamilan atau selama periode postpartum (Brown, Johnston, 2013).

Saat kehamilan ketika membusungkan tubuh, rahim akan terdorong ke depan, dan karena rahim hanya ditahan ligamen dari belakang dan bawah (kanan), maka ligamen tersebut akan tegang dan menyebabkan rasa nyeri di pangkal paha serta sebagian kecil punggung (Pierce, 2007). Hormon progesteron dan hormon relaksasi menyebabkan relaksasi jaringan ikat dan otot-otot. Hal ini terjadi maksimal pada satu minggu terakhir kehamilan. Proses relaksasi ini memberikan kesempatan pada panggul untuk meningkatkan kapasitasnya sebagai persiapan persalinan, tulang pubis melunak menyerupai tulang sendi, sambungan sendi sacrococcigus mengendur membuat tulang 
koksigis bergeser ke arah belakang sendi panggul yang tidak stabil. Pada ibu hamil, hal ini dapat menyebabkan sakit pinggang.

Postur tubuh wanita secara bertahap mengalami perubahan karena janin membesar dalam abdomen sehingga untuk mengompensasi penambahan berat badan ini, bahu lebih tertarik ke belakang dan tulang lebih melengkung, sendi tulang belakang lebih lentur dan dapat menyebabkan nyeri punggung pada beberapa wanita (Vivian, Sunarsih, 2011). Gejala-gejala nyeri punggung menurut West (2010) rasa sakit sepanjang punggung atau panggul, lemah atau sakit pada bagian bokong dan kaki, sulit berjalan karena sakit pada kaki.

Pada studi hanya sedikit para ibu hamil mencari pertolongan medis saat nyeri punggung bawah timbul.Sebagian besar ibu hamil trimester III yang mengalami nyeri punggung bawah, hanya $23(13,33 \%)$ yang melakukan konsultasi pada bidan dan tenaga kesehatan mengenai masalah yang dialaminya. Didapatkan sebagian besar ibu hamil mengetahui mengenai fisiologis nyeri punggung bawah berdasarkan informasi dari keluarga dan suami sedangkan informasi dari dokter hanya sebesar 3,5\%. Dalam studi lainnya ditemukan bahwa pada wanita hamil di trimester ketiga nyeri punggung bawah lebih banyak terjadi dengan prevalensi sebanyak (43,24\%) (Katonis et al, 2011). Penelitian sebelumnya juga menemukan bahwa prevalensi nyeri punggung bawah lebih tinggi pada wanita hamil dari trimester ketiga, dengan dari sebagian besar responden lebih memilih minum air hangat/memijat area punggung bawah saat terjadi nyeri. Hal ini sejalan dengan hasil penelitian yang telah peneliti lakukan.

\section{SIMPULAN}

Studi ini menunjukkan bahwa nyeri punggung bawah pada ibu hamil trimester III terjadi dengan prevalensi terbanyak pada skala nyeri sedang. Peningkatan usia kehamilan dan temuan ini empa-ukuran asal biomekanik nyeri pinggang pada wanita hamil. Nyeri punggung bawah sering ditemukan pada kehamilan. Hal ini dapat menjadi indikasi pentingnya edukasi kesehatan tentang nyeri punggung bawah untuk ibu hamil selama trimester III dan suami serta keluarganya, dan evaluasi rutin masalah nyeri punggung bawah oleh para klinisi.

\section{SARAN}

Berdasarkan hasil yang diberikan oleh studi ini mengenai nyeri punggung bawahselama kehamilan, penelitian selanjutnya disarankan untuk pemberian intervensi dalam penanganan nyeri punggung bawah pada ibu hamil trimester III. 


\section{DAFTAR PUSTAKA}

Pierce, A. G., Borley, R. N. (2007). At a Glance Ilmu Bedah Edisi Ketiga. Jakarta: Erlangga. P. 14-15

Ariyanti. (2012). Apakah Ada Pengaruh WWZ terhadap Perubahan Skala Nyeri Punggung pada Ibu Hamil di Puskesmas Perawatan Ngletih Kota Kediri

Bobak. (2010). Buku Ajar Keperawatan Maternitas Edisi 4. Jakarta: EGC

Brown, A., \& R. Johnston. (2013). Maternal Experience of Musculoskeletal Pain during Pregnancy and Birth Outcomes: Significance of Lower Back and Pelvic Pain. Midwifery, 29(13), 46-51

Burns, S. A., Joshua A. C., Darren, A. R., \& Suzanne J. S. (2018). Effectiveness of Physical Therapy Interventions for low Back Pain Targeting the Low Back only or Low Back Plus Hips: a Randomized Controlled Trial Protocol. Brazilian Journal of Physical Therapy

Carvalho, M. E. C. C., Luciana. C. L., Cristovam, A. L. T., Deyvid, R. L. P., Marcelo N. S., Gustavo, A. C., \& Tania, C. M. C. (2017a). Low Back Pain during Pregnancy. Revista Brasileira de Anestesiologia, 67(2), 66-70

. (2017b). Low Back Pain during Pregnancy. Brazilian Journal of Anesthesiology (English Edition), 67(2), 66-70

Darwich, A. A., \& Sudhir A. D. (2009). Management of Back Pain in Pregnancy', Techniques in Regional Anesthesia and Pain Management, 13(2), 51-54

Dewi, V. N. L., Sunarsih, T. (2011). Asuhan Kebidanan Ibu Nifas. Jakarta: Salemba Medika

Durand., Guillaume., \& Erika, M. P. (2017). The Effects of Psychopathic Traits on Fear of Pain, Anxiety, and Stress, Personality and Individual Differences, 119, 198-203

Elsevier. (2011). Neurological Disorders and Pregnancy 1st Edition. In: Elsevier

Golob, A. L., \& Joyce, E. W. (2014). Low Back Pain. Medical Clinics of North America, 98(40), 5-28

Hartvigsen., Jan., Mark J. H., Alice K., Quinette, L., Manuela L. F., Stéphane, G., Damian, H, Jaro. K., Glenn, P., Joachim, S., Rob J. S., Martin, U., Rachelle B., Jan, H., Dan, C., Nadine, E. F., Chris, G. M., Martin U., Maurits, V. T., Johannes R. A., Roger, C., Stephen, P. C., Lucíola, Menezes C., Peter, C., Manuela, F, Paulo, H. F., Julie, M. F., Stéphane, G., Douglas, P. G., Mark, J. H., Damian, H., Jaro, K., Bart, W. K., Alice, K., Quinette, L., Birgitta, Ö., Wilco, C. P., Glenn P., Mark, S., Joachim, S., Rob, J. S., Judith, A. T, \& Anthony, W. (2018). What Low Back Pain is and Why We Need to Pay Attention. The Lancet, 391(23), 56-67

Katonis, P. A., Kampouroglou, A., Aggelopoulos, K., Kakavelakis, S., Lykoudis, A., Makrigiannakis., \& Alpantaki, K. (2011). 'Pregnancy-Related Low Back Pain', Hippokratia, 15, 205

Lee., Diane. (2016). Chapter 17 - Highlights from an Integrated Approach to the Treatment of Pelvic Pain and Dysfunction A2 - Magee, David J. in James E. Zachazewski, William S. Quillen and Robert C. Manske (eds.). Pathology and Intervention in Musculoskeletal Rehabilitation (Second Edition) (W.B. Saunders)

Lima., Maicom., Arthur, S. F., Felipe, J. J. R., Vanessa, P, \& Ney, M. H. (2018). 'Chronic low back pain and back muscle activity during functional tasks', Gait \& Posture, 61(2), 50-56

Manuaba,I. B. G. (2010). Gawat Darurat Obstetri Ginekologi dan Obstretri Ginekologi Sosial untuk Profesi Bidan. Jakarta: EGC 
Nickel, B. T., Mitchell, R. K., William, A. B., David, E. A., Thorsten, M. S., \& Samuel S. W. (2018). Battling the Opioid Epidemic with Prospective Pain Threshold Measurement. The Journal of Arthroplasty

Renata. (2009). Askep Nyeri Punggung. http://www.scribd.com/doc/52688087/askebnyeri-punggung

Tiran. (2008). Bailliere's Midwives' Dictionary. Bailliere Tindall

West, Z. (2010). Natural Pregnancy. Jakarta: Pustaka Bunda

Yan, C. F., Ya-Chi, H., Meei-Ling, G., \& Kuan-Chia, Lin. (2014). Effects of a Stability Ball Exercise Programme on Low Back Pain and Daily Life Interference during Pregnancy. Midwifery, 30(4), 12-19 